\title{
THE NUTRITIVE EVALUATION OF COCKSFOOT PASTURE UNDER DIFFERENT LEVELS OF NITROGEN FERTILIZATION
}

\author{
R. L. Reid, Amy J. Post AND G. A. JUNG \\ West Virginia University, U.S.A.
}

DuRING the past few years, increasing emphasis has been placed on the use of nitrogen fertilized grass species, rather than grass-legume mixtures, in the North-eastern United States. According to Washko et al. (1967), factors contributing to this trend have been the spread of the alfalfa weevil, development of improved, high yielding grass varieties, the availability of nitrogen fertilizer at economical prices, better harvesting and storage techniques, and the demonstration that grasses fertilized adequately and cut early are equivalent to legumes in nutritive quality. Of the different grass species examined, cocksfoot (Dactylis glomerata) has been shown to respond well to nitrogen fertilization, to be highly competitive, and to recover well under severe cutting managements. It has been claimed that cocksfoot is inferior nutritionally to other grasses. This was not substantiated in sheep feeding trials with herbage cut at different growth stages (Reid et al., 1962; Reid and Jung, 1965, or in subsequent grazing trials (Reid, Jung and Kinsey, 1967).

The application of high levels of nitrogen fertilizer to grass stands causes changes in the composition of the herbage which may affect its utilization by the grasing animal. Effects on such factors as rate of gain, dry matter digestibility, intake, palatability, mineral utilization, in 1 vitamin A status of cattle and sheep have been den,,... strated. It has, on the other hand, also been suggested that heavy nitrogen fertilization on grassland may have comparatively little influence on the nutritional and reproductive performance of ruminants (e.g., Hodgson and Spedding, 1966; de Groot, 1967). The following study was designed to determine the effects of four fertilizer treatments (low nitrogen, $56 \mathrm{~kg} \mathrm{~N} / \mathrm{ha}$; medium nitrogen, $168 \mathrm{~kg}$ $\mathrm{N} / \mathrm{ha}$; high nitrogen, $504 \mathrm{~kg} \mathrm{~N} / \mathrm{ha}$ : high nitrogen + trace elements, $504 \mathrm{~kg} \mathrm{~N} / \mathrm{ha} .+\mathrm{Zn}$, Cu. MD, Co, S) on the nutrition of a flock of ewes maintained on cocksfoot alone-i.e., pasture from spring through autumn and hay made from 
the same fertilizer treatments during the winter-over a 4-year period beginning in 1967. The trace element treatment was included because, in another study (Reid et al., 1969), consistent increases in the dry matter digestibility of first cutting cocksfoot hays by sheep had been obtained in response to the addition of micro-elements and/or magnesium to NPK fertilizer.

In each year the ewes were maintained on replicated pastures at a light stocking rate, so that availability of herbage was not limiting. Wethers were added as required in the spring to maintain the herbage at approximately 20 to $25 \mathrm{~cm}$ in height and stemmy top growth was removed by mower in June. Hay was made from adjacent replicated plots under the same fertilizer treatments at the early heading growth stage in the first growth cycle, and from regrowth herbage in late summer. This was supplied to the sheep in feeding racks on pasture when grass became limiting in late autumn, and was fed ad libitum when the ewes were brought into the barn for lambing. Animals were dosed alternately with thibendazole and phenothiaiine at 21-day intervals throughout the year. Common salt was supplied as the sole mineral supplement during the first year, at which time serum phosphorus values had declined to low values; a 50: 50 mixture of salt and dicalcium phosphate has since been available to the ewes.

\section{LIVEWEIGHT CHANGES AND REPRODUCTIVE PERFORMANCE}

\section{OF EWES}

Weight gains have been recorded on the ewes monthly over a 30-month period since the beginning of the trials and little difference has been noted between animals on the different fertilizer treatments during the spring and summer grazing periods. Ewes on the high nitrogen and high nitrogen + trace element treatments, however, maintained a significantly higher liveweight during the winter months after the initiation of hay feeding. These differences became more pronounced during the second winter, and animals on the trace element treatment maintained a higher body-weight than ewes on high nitrogen alone. In the first lamb crop, in 1968, there were no significant differences between treatments in the birth-weight of either single or twin lambs. There was, however, a significant incidence of thyroid enlargement and histological abnormality in lambs born from the high nitrogen groups, with the highest thyroid weights being recorded on the 
trace element treatment. In the 1969 crop, the birth-weight of lambs was uniformly lower than in 1968. There were again no differences between treatments in the birth-weight of single or twin lambs but the weight of lambs produced per ewe was higher on the high nitrogen treatments, particularly the trace element group, owing to the increased

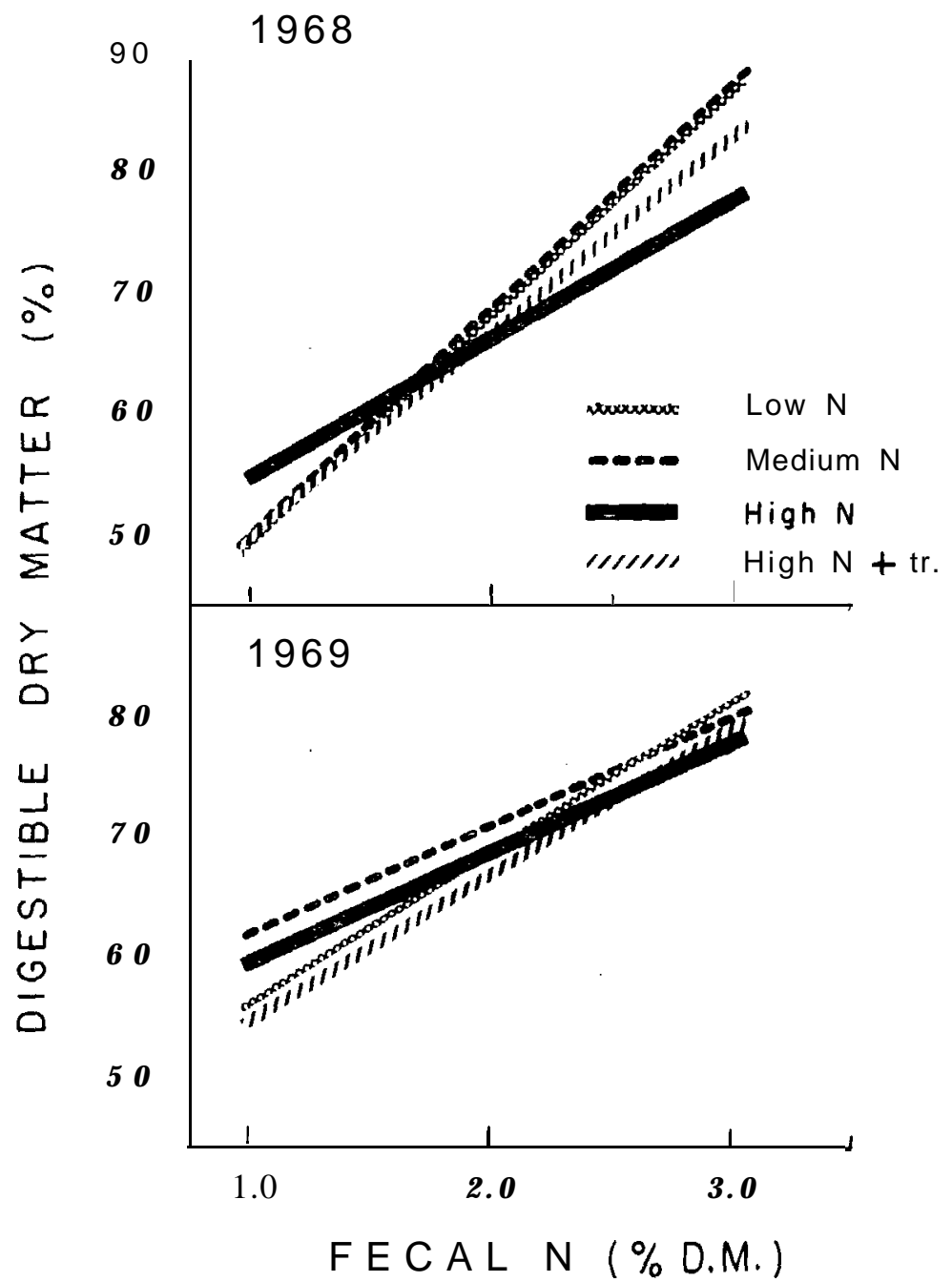

FIG. 1: Dry matter digestibility/faecal nitrogen regressions obtained under different fertilization treatments in 1968 and 1969. 
percentage of multiple births. There were no differences in lamb thyroid weights between treatments in 1969 , although histological abnormality was evident. A high mortality rate was noted in ewes and lambs on the low and medium nitrogen treatments in 1969. Approximately $30 \%$ of ewes in these groups died during the last 2 or 3 weeks of pregnancy, death being related to a severe anemia. The anemia was apparently not related to parasitic infestation. The highest incidence of successful lambing, of lambs surviving, and of maximum growth of lambs on pasture, was recorded in each year on the high nitrogen + trace element treatment.

\section{PASTURE EVALUATION TRIALS}

The effects of fertilization on the digestibility and intake of grazed herbage by dry and lactating ewes were determined in 1968 and 1969. Dry matter digestibility was estimated using "local" regression equations with faecal nitrogen as indicator (Greenhalgh and Corbett, 1960). In each year, cut herbage was fed at constant intake to housed wethers for periods of seven days at vegetative, early heading and full bloom stages of the cocksfoot. Concurrently, dry and lactating ewes on pasture were dosed twice daily with chromic oxide and grab samples of faeces collected. In 1969, dry matter digestibility/faecal nitrogen relationships were determined on different fractions of herbage, the whole plant, and top and bottom portions obtained by use of a forage harvester set at half the height of the whole plant. In 1969 also, digestibility/faecal nitrogen relationships were determined with the rabbit; concurrent trials were run with rabbits in metabolism cages fed cut herbage at constant intake and with animals kept in individual cages on pasture. The cages were moved daily and faecal samples collected from the sward.

Regression relationships between dry matter digestibility and concentration of faecal nitrogen obtained with wethers fed cut whole herbage in 1968 and 1969 are given in Fig. 1. Previous workers (e.g., Greenhalgh et al., 1960; Reid, Odhuba and Jung, 1967) found that the effect of nitrogen fertilization on digestibility/faecal nitrogen regression coefficients was relatively small when compared with the effect of season. This was apparent also in this study. The effect of year was significantly greater than that of fertilizer treatment within year.

It has been suggested (Raymond, 1966) that the faecal index method for predicting the digestibility of herbage 
by grazing animals may be invalid, owing to the differences in digestibility/faecal nitrogen regressions obtained with different parts of the plant. In the 1969 trials, digestibility/ faecal nitrogen regressions were calculated for groups of wethers fed either cut whole cocksfoot or the top or bottom fractions of the plant. From Fig. 2 it can be seen that the regression lines obtained with different plant parts were not significantly different. This result is at variance with the findings of Pearce et al. (1962) with sheep, but is in agreement with the data of Greenhalgh et al. (1966) obtained with cattle. It tends to indicate that regression equations obtained with harvested whole cocksfoot may be applied to the determination of the digestibility of herbage selected by the grazing ewe.

Digestibility and intake data obtained with wethers and dry and lactating ewes are summarized in Table 1. Dry matter digestibility of the cut herbage declined with advancing maturity at rates characteristic of forage crops in the North-eastern United States, although the rate of decline differed between years: a mean decrease of 0.50

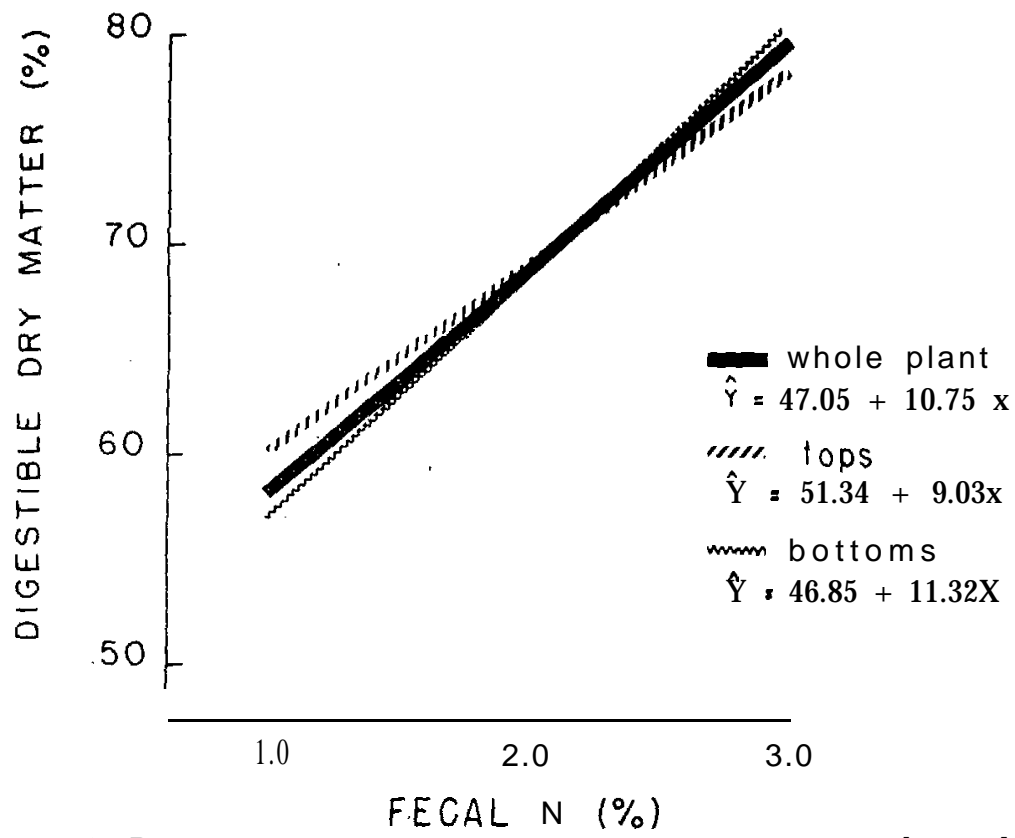

FIG. 2: Dry matter digestibility/faecal nitrogen regressions obtained with different plant fractions in 1969. 
TABLE 1: EFFECT OF FERTILIZER TREATMENT ON DIGESTIBILITY OF CUT HERBAGE BY WETHERS IN FEEDING TRIALS, AND ON DIGESTIBILITY AND INTAKE OF PASTURE BY DRY AND LACTATING EWES

\begin{tabular}{|c|c|c|c|c|c|c|c|c|c|c|c|c|}
\hline \multirow{2}{*}{\multicolumn{2}{|c|}{$\begin{array}{l}\text { Growth Stage and } \\
\text { Fertilizer Treatment* } \\
\text { Wethers }\end{array}$}} & \multicolumn{2}{|c|}{$\begin{array}{l}\text { Digestibility of } \\
1968\end{array}$} & \multicolumn{2}{|c|}{$\begin{array}{c}\text { Dry Matter }(\%) \\
1969\end{array}$} & \multirow[b]{2}{*}{$\begin{array}{l}\text { Lact. } \\
\text { Ewes }\end{array}$} & \multicolumn{2}{|c|}{$\begin{array}{l}\text { Apparent } \\
\text { Digestibility } \\
\text { of Protein }(\%) \\
1968 \quad 1969\end{array}$} & \multicolumn{4}{|c|}{ 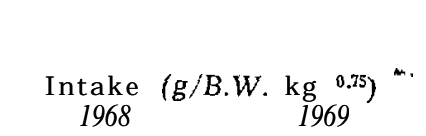 } \\
\hline & & $\begin{array}{l}\text { Dry } \\
\text { wes }\end{array}$ & $\begin{array}{l}\text { Lact. } \\
\text { Ewes }\end{array}$ & Wethers & $\begin{array}{c}\text { Dry } \\
\text { Ewes }\end{array}$ & & Wethers & Wethers & $\begin{array}{l}\text { Dry } \\
\text { Ewes }\end{array}$ & $\begin{array}{l}\text { Lact. } \\
\text { Ewes }\end{array}$ & $\begin{array}{l}\text { Dry } \\
\text { Ewes }\end{array}$ & $\begin{array}{l}\text { Lact. } \\
\text { Ewes }\end{array}$ \\
\hline \multicolumn{13}{|l|}{ Vegetative, leafy: } \\
\hline Low & 78.5 & 86.9 & 86.1 & 73.2 & 78.5 & 79.6 & 74.6 & 72.5 & 139 & 147 & 123 & 145 \\
\hline Medium $\quad \mathrm{N}$ & 77.3 & 83.5 & 81.5 & 74.7 & 80.1 & 81.3 & 77.8 & 79.5 & 125 & 136 & 132 & 169 \\
\hline High $\mathrm{N}+\mathrm{N}_{\text {Trace }}$ & $\begin{array}{l}75.9 \\
77.5\end{array}$ & $\begin{array}{l}79.4 \\
81.9\end{array}$ & $\begin{array}{l}80.9 \\
85.4\end{array}$ & $\begin{array}{l}74.3 \\
73.1\end{array}$ & $\begin{array}{l}80.0 \\
80.5\end{array}$ & $\begin{array}{l}79.7 \\
80.8\end{array}$ & $\begin{array}{l}79.4 \\
71.3\end{array}$ & $\begin{array}{l}84.0 \\
82.9\end{array}$ & $\begin{array}{r}85 \\
86\end{array}$ & $\begin{array}{l}101 \\
105\end{array}$ & $\begin{array}{l}129 \\
124\end{array}$ & 125 \\
\hline \multicolumn{13}{|c|}{ Early head: } \\
\hline Low & 67.3 & 78.0 & 77.3 & 65.3 & 68.8 & 70.0 & 57.9 & 55.3 & 109 & 114 & 110 & 118 \\
\hline $\begin{array}{ll}\text { Medium } & \mathrm{N} \\
\text { High } & \mathrm{N}\end{array}$ & $\begin{array}{l}67.2 \\
68.3\end{array}$ & $\begin{array}{l}79.1 \\
744.0\end{array}$ & $\begin{array}{l}76.4 \\
73.0\end{array}$ & $\begin{array}{l}67.5 \\
66.1\end{array}$ & $\begin{array}{l}72.6 \\
70.0\end{array}$ & $\begin{array}{l}72.6 \\
69.0\end{array}$ & $\begin{array}{l}65.8 \\
65.9\end{array}$ & $\begin{array}{l}73.2 \\
79.3\end{array}$ & $\begin{array}{r}112 \\
82\end{array}$ & $\begin{array}{r}113 \\
82\end{array}$ & $\begin{array}{l}115 \\
104\end{array}$ & $\begin{array}{l}124 \\
113\end{array}$ \\
\hline High $N+$ Trace & 64.8 & 78.6 & 76.8 & 62.3 & 71.8 & 70.3 & 68.2 & 76.0 & 76 & 102 & 109 & 125 \\
\hline Fuddwbloom: $\mathrm{N}$ & 59.4 & 67.6 & 67.9 & 61.6 & 66.9 & 65.6 & 31.6 & 47.0 & 81 & 91 & 128 & 139 \\
\hline Medium & 60.0 & 68.4 & 66.6 & 59.8 & 68.9 & 68.9 & 43.6 & 50.1 & 86 & 88 & 147 & 157 \\
\hline High & 59.6 & 65.4 & 63.2 & 57.5 & 69.4 & 73.0 & 57.2 & 69.3 & 76 & 84 & 133 & 137 \\
\hline High $\mathrm{N}+$ Trace & 58.3 & 65.0 & 67.8 & 55.8 & 70.9 & 71.0 & 56.9 & 67.2 & 57 & 101 & 119 & 141 \\
\hline
\end{tabular}


percentage units per day in 1968, and of 0.37 units per day in 1969. In confirmation of other reports (Blaser, 1964), level of nitrogen fertilization had no significant effect on the dry matter digestibility of cut herbage, although there were in both years significant increases in the apparent digestibility of crude protein associated with increased rates of nitrogen application.

Using regressions obtained with whole herbage, the estimated dry matter digestibility of herbage selected by dry and lactating ewes over all fertilizer treatments in both years was found to average approximately 7 percentage units higher than for the harvested grass. There appeared to be no consistent effect of growth stage, year or fertilizer treatment on this increased digestibility attribtued to selective grazing. In both years there was a significant decline in the dry matter digestibility of the pasture herbage as it matured from the vegetative to the full bloom stage, but no effect of fertilizer treatment. Analysis of the data also showed that there were no differences in dry matter digestibility between the groups of dry and lactating ewes.

Herbage intake of the grazing ewes was calculated from faecal output data as determined by faecal chromic oxide analysis. In 1968 there was a decline in intake with increasing maturity of the pasture, and the rate of decline was related to the fertilization treatment. In 1969, the level of intake decreased on all treatments from the vegetative to the early heading stage, and then increased again at the full bloom stage. This may have been due in part to an increased growth of aftermath herbage in 1969, when rainfall conditions were particularly favourable in early summer. It was of interest to find that, while the level of nitrogen fertilization had no effect on dry matter digestibility, it did significantly affect the level of intake. In both years, the intake of dry matter by ewes on the low and medium nitrogen treatments was higher than on the high nitrogen treatments; this effect was particularly marked in the early growth period in 1968, when the estimated intake by all ewes on low and medium nitrogen treated grass was approximately $50 \%$ higher than on high nitrogen herbage.

Previous studies (e.g., Hutton, 1963) have shown that lactating cattle and sheep have higher rates of forage intake than dry animals. A significant difference in herbage intake between lactating and dry ewes was confirmed in the two years of these trials. Expressed as a mean of all fertilizer treatments, lactating ewes consumed $11 \%, 9 \%$ and $19 \%$ more dry matter than dry ewes at the vegetative, head- 
ing and full bloom stages, respectively, in 1968; corresponding increases of 13\%, 9\% and 9\% were obtained in 1969.

A summary of results for the estimated intake of digestible dry matter by all ewes in 1968 and 1969 is presented in Fig. 3. Statistical analysis indicated that there were differences due to (a) year, (b) stage of growth of the pasture, (c) fertilizer treatment, (d) state of the ewei.e., whether dry or lactating. In general, the effects of growth stage and level of fertilization were more pronounced in 1968 than in 1969. In both years, an attempt was made to define effects of treatment on the nutritive quality of the herbage per se by stocking the pastures below the optimum rate. The changes due to fertilization

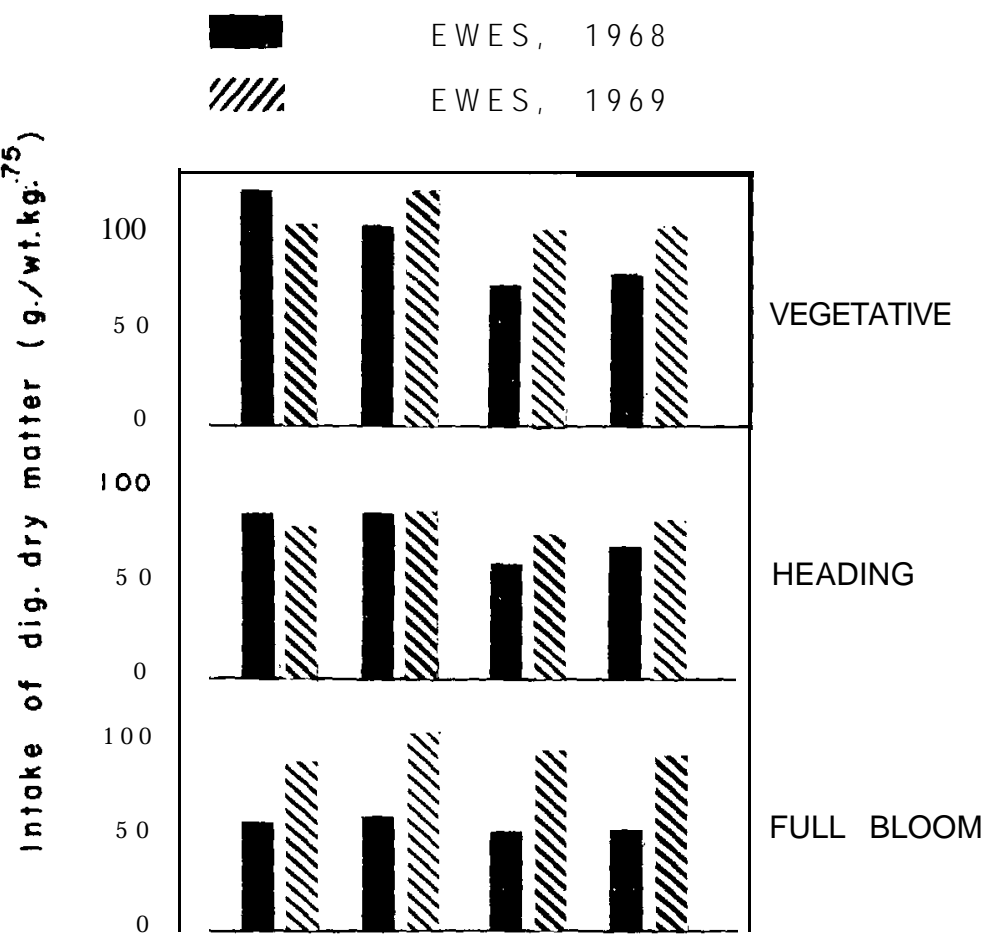

Low $\mathrm{N}$ Med.N High $\mathrm{NHigh} \mathrm{N}$

trace

FIG. 3: Influence of year, growth stage of pasture and fertilizer treatment on intake of digestible dry matter by grazing ewes in 1968 and 1969. 
should therefore be considered in relation to differences in yield potential of the pastures.

Earlier studies have related digestibility and intake data obtained with the rabbit to results obtained with sheep or cattle (e.g., Ingalls et al., 1965). A comparison of dry matter and protein digestibility coefficients for cut herbage by wethers and by rabbits in 1969 showed that, while digestibility coefficients for the two species were quantitatively different, they were highly correlated. The same effects of fertilizer treatment on digestibility were noted with the rabbit as with the sheep. Examination of dry matter digestibility/faecal nitrogen relationships in the rabbit indicated that these differed markedly from those, calculated for the sheep, and that fertilizer treatment had a significant effect on the regression curves obtained.

\section{NITRATE EFFECTS AND VITAMIN A STATUS OF SHEEP}

It has been suggested that high levels of nitrogen fertilization on forage crops may, by increasing the plant concentration of nitrate, create metabolic problems in ruminant animals. Blood methaemoglobin, rumen and blood ammonia, and blood urea values were determined at monthly intervals in the grazing ewes during the first year of the trials. It was found that, while grass nitrate levels were higher on the high nitrogen fertilizer pastures, and increased to approximately $2 \%$ at certain periods of the year, there was no marked increase in blood methaemoglobin at any time, and values never approached the levels associated with nitrate toxicity. No differences in blood ammonia concentration due to treatment were obtained at any period of the. year, although effects on rumen ammonia concentrations were noted,

There have been reports (Hinds et al., 1969) that the liver vitamin A stores of beef cattle grazing nitrogen fertilized grass may be low. Blood and liver carotene and vitamin A levels have been determined at regular intervals in these trials on ewes, on new-born lambs and on lambs maintained for 16 weeks on pasture with their dams. There has been no indication of a depletion of vitamin A associated with high levels of nitrogen fertilization, Rather, the trend has been for increased liver vitamin A storage by the ewes to be related to plant carotene concentrations, which have in turn been related to the amount of nitrogen applied to the pasture. 


\section{REFERENCES}

Blaser, R. E., 1964: Symposium on forage utilization; effects of fertility level and stage of maturity on forage nutritive value. J. Anim. Sci., 23: 246-53.

de Groot, Th., 1967: The grazing dairy cow in relation to its environment under intensive farming conditions. In Report of Proceedings and Invited Papers of the 9th Int. Cong. of Anim. Prod., Edinburgh, 1966: 165-73. Oliver and Boyd.

Greenhalgh, J. F. D.; Corbett, J. L., 1960: The indirect estimation of the digestibility of pasture herbage. I. Nitrogen and chromogen as faecal index substances: J. agric. Sci., Camb., 55: 371-6.

Greenhalgh, J. F. D.; Corbett, J. L.; McDonald, I., 1960: The indirect estimation of the digestibility of pasture herbage. II. Regressions of digestibility on faecal nitrogen concentration; their determination in continuous digestibility trials and the effect of various factors on their accuracy. Ibid., 55: 377-86.

Greenhalgh, J. F. D.; Reid, G. W.; McDonald, I., 1966: The indirect estimation of the digestibility of pasture herbage. IV. Regressions of digestibility on faecal nitrogen concentration; effects of different fractions of the herbage upon within-and betweenperiod regressions. Ibid., 66: 277-83.

Hinds, F. C.; Cmarik, G. F.; Mansfield, M. E.; McKibben, G. E., 1969: Vitamin A status of beef cattle grazing cocksfoot. J. Anim. Sci., 29: 180

Hodgson, J.; Spedding, C. R. W., 1966: The health and performance of the grazing animal in relation to fertilizer nitrogen usage. I. Calves. J. agric. Sci., Camb., 67: 155-67.

Hutton, J. B., 1963: The effect of lactation on intake in the dairy cow. Proc. N.Z. Soc. Anim. Prod. 23: 39-52.

Ingalls, J. R.; Thomas, J. W.; Tesar, M. B., 1965: Comparison of responses to various forages by sheep, rabbits, and heifers. J. Anim. Sci., 24: 1165-8.

Pearce, G. R.; Vercoe, J. E.; Freer, M., 1962: The establishment of faecal nitrogen-digestibility regressions for animals grazing irrigated pasture. J. agric. Sci., Camb., 59: 397-402.

Raymond, W. F., 1966: The nutritive value of herbage. In Recent Advances in Animal Nutrition, ed. J. T. Abrams: 81-118.

Reid, R. L.; Clark, B.; Welch, J. A.; Dosza, L.; Jung, G. A., 1962: Investigation of plant species and maturity stage on forage nutritive value as determined by in vitro digestion techniques. U.S.D.A. Contract No. 12-14-100-4524 (24) W. Va. Agric. Exp. Sta.

Reid, R. L.; Jung, G. A., 1965: Factors influencing the intake and palatability of forages by sheep. Proc. 9th int. Grassld Congr.: 863-9.

Reid, R. L.; Jung, G. A.; Kinsey, C. M., 1967: Nutritive value of nitrogen fertilized cocksfoot pasture at different periods of the year. Agron. J., 59: 519-25.

Reid, R. L.; Jung, G. A.; Post, Amy J., 1969: Effects of micro-element fertilization on nutritive quality of cocksfoot. J. Anim. Sci., 29: 181 . 
Reid, R. L.; Odhuba, E. K.; Jung, G. A.; 1967: Evaluation of tall fescue pasture under different fertilization treatments. Agron. J., 59: 265-71.

Washko, J. B.; Jung, G. A.; Decker, A. M.; Wakefield, R. C.; Wolf, D. D.; Wright, M. J., 1967: Management and productivity of perennial grasses in the North-east. III: Cocksfoot. W. Va. Univ. Agr. Expt. Sta. Bull. 557T.

\section{DISCUSSION}

Marten (U.S.A.) asked if moisture content of the grasses at different stages of growth in the different treatments and relative palatability had been taken into account as a possible explanation of differences obtained. Reid said there were marked differences in water content at different stages of growth and in intake, but water was not the main determining factor. A definition of palatability was needed. He had carried out palatability trials indoors. For instance, animals offered a choice had rejected high- $\mathrm{N}$ grass in favour of low- $N$ grass. It was hard to translate from indoors to outdoors. In the latter there were complicating factors such as differences in yields. The quantity available was most important. As the level of $\mathbf{N}$ increased, the available soluble carbohydrate dropped and this could affect intake.

Butler asked if the goitre reported could have been controlled by iodine supplementation or was it a direct effect of higher bloodnitrate, itself a goitrogenic principle. Reid said he had found in experiments with rats that he could obtain a reversal of the thyroid effect with added iodine and could expect the same with sheep. Supplementation experiments had been started with two groups of sheep, one plus iodine, one without, and they would be continued to estimate the effect on the new-born lamb. He would also be checking on the nitrate effect by adding doses of nitrate in feed to animals. 